ROCZNIKI HUMANISTYCZNE

Tom LXIX, zeszyt $12-2021$

DOI: https://doi.org/10.18290/rh216912-6

\title{
ORGANY W KOŚCIOŁACH DEKANATU OPATOWSKIEGO DIECEZJI SANDOMIERSKIEJ. INSTRUMENTY NIEZACHOWANE W ŚWIETLE ŹRÓDEŁ ARCHIWALNYCH
}

\section{WPROWADZENIE}

Niniejszy artykuł jest kontynuacją cyklu tekstów autorki na temat organów i organistów w diecezji sandomierskiej. Dotychczas ukazały się dwa artykuły dotyczące niezachowanych instrumentów w dekanatach ożarowskim i zawichojskim (Szymanowicz, Organy w kościołach dekanatu ożarowskiego; Organy w kościołach dekanatu zawichojskiego), w przygotowaniu jest Leksykon muzyków kościelnych diecezji sandomierskiej 1818-1992.

Podstawą niniejszego opracowania są przede wszystkim źródła archiwalne zachowane w Archiwum Kapituły Metropolitalnej w Krakowie, Archiwum Kurii Metropolitalnej w Krakowie, Bibliotece Wyższego Seminarium Duchownego w Sandomierzu, Archiwum Diecezjalnym w Sandomierzu oraz Archiwum Państwowym w Radomiu. W Krakowie oraz w Bibliotece WSD w Sandomierzu przechowywane są XVIII-wieczne protokoły wizytacji biskupich, w których znajdują się krótkie zapisy o organach. W Archiwum Diecezjalnym wykorzystano akta parafialne, które zawierają zbiór wszelkich akt z XIX, XX i XXI wieku dotyczących danej parafii: inwentarze kościołów, wizytacje pasterskie i dziekańskie oraz inne dokumenty. W Radomskim Archiwum Państwowym zachowane są XIX-wieczne akta funduszów parafii oraz reperacji kościołów.

Dr hab. MARIA SzYMANOwicz, prof. KUL - Katolicki Uniwersytet Lubelski Jana Pawła II, Instytut Nauk o Sztuce; adres do korespondencji: Al. Racławickie 14, 20-950 Lublin; e-mail: maria.szymanowicz@kul.pl; ORCID: https://orcid.org/0000-0001-7102-1675.

Dr. Hab. Maria Szymanowicz, Associate Professor at the John Paul II Catholic University of Lublin, Institute of Art Studies; address for correspondence: Al. Racławickie 14, 20-950 Lublin, Poland; e-mail: maria.szymanowicz@kul.pl; ORCID: https://orcid.org/0000-0001-7102-1675. 
Przeprowadzona eksploracja powyższych źródeł i analiza uzyskanych danych pozwoliły na opracowanie zagadnienia historii organów w kościołach dekanatu opatowskiego. Uwzględniono aktualny podział administracyjny diecezji sandomierskiej.

Tekst składa się z dwóch części. W pierwszej zamieszczono informacje o organach niezachowanych w poszczególnych parafiach w sposób uporządkowany chronologicznie. Określenie np. „Pozytyw sprzed 1718 r.” oznacza, że informacja o tym instrumencie, na jaką udało się autorce natrafić, pojawiła się po raz pierwszy w źródle z roku 1718. Podano także zwięzłe dane o instrumentach istniejących obecnie. Druga część to podsumowanie badań. Pogrupowano w niej uzyskane dane według następujących zagadnień: liczba organów, nazewnictwo, lokalizacja i wygląd zewnętrzny, wielkość i rodzaj instrumentów oraz inne szczegóły, a wśród nich budowniczowie i fundatorzy oraz dane konstrukcyjne.

\section{INFORMACJE O ORGANACH \\ W KOŚCIOŁACH DEKANATU OPATOWSKIEGO}

\section{Gierczyce, parafia pw. św. Mikołaja Bp.}

Parafia erygowana w 1390 r. Kościół parafialny został wzniesiony w roku 1708 r. na miejscu pierwotnego. Jest drewniany, oszalowany, o konstrukcji zrębowej. Od strony północnej w 1796 r. dobudowano murowaną zakrystię (Rocznik diecezji 260-61).

\subsection{Pozytyw szkatulny sprzed $1718 \mathrm{r}$.}

W wizytacji kościoła gierczyckiego z 1718/19 r. wymieniony jest pozytyw szkatulny usytuowany na drewnianym chórze muzycznym: „Chorus Musicus ligneus supra portam ad porticum cum parvo instrumento Musico dicto posijtew Szkatulnij indigente reparatione" (AKap.MK, sygn. AVCap. 58, 159). Zapis (który potrzebuje naprawy) sugeruje, że instrument pochodził z XVII w. Z kolejnego źródła wiadomo, że ów pozytyw miał 6 głosów (AKMK, sygn. AV 45, 1v).

\subsection{Pozytyw z 1796 r.}

Następny instrument powstał w $1796 \mathrm{r}$. Informację o nim przekazuje opis kościoła z 1816 r.: ,[...] chur z Organami nowemi stosownie do Mozaiki Kościelnej w dobrym stanie existuią” (APR, sygn. RGR I 5690, 75) oraz inwentarz kościoła z 1826 r.: „pozytew stoiący, o głosach dziewięciu, w Roku 1796 nowo sprawiony, z frontu gustownie Rzeźbami wyzłoconemi przyozdobiony" (ADS, 
Akta parafii Gierczyce [1826] 1845-1983, 19r). Instrument umieszczony był nad wielkimi drzwiami, na drewnianym, malowanym i przyozdobionym rzeźbami chórze muzycznym. Wymieniany jest w kolejnych inwentarzach kościoła - z 1871 i 1887 r. (ADS, Akta parafii Gierczyce [1826] 1845-1983, 174r, 209r, 230r).

Obecnie w kościele gierczyckim funkcjonują 7-głosowe organy $(\mathrm{M}+\mathrm{P})$ zbudowane w latach 1968/69 przez Jana Włodarkiewicza (Lipa 295). Zachowana została XVIII-wieczna szafa organowa.

\section{Iwaniska, parafia pw. św. Katarzyny Dziewicy i Męczennicy}

Parafia została erygowana w II poł. XV w. Kościół pierwotny spłonął, kolejny zaś modrzewiowy, wybudowany w 1718 r., spłonął w roku 1898. Obecną świątynię zbudowano z cegły w latach 1900-1905 (Rocznik Diecezji 262-63).

\subsection{Pozytyw przenośny sprzed $1727 \mathrm{r}$.}

Nowo wybudowaną świątynię ozdobiły małe organy umieszczone na chórze muzycznym. Pierwsza informacja o tym instrumencie zawarta jest w protokole wizytacyjnym parafii w Iwaniskach z 1727 r. Wymieniono w nim „Chorus Musicalis cum Organo parvo" (AKMK, sygn. AV 22, 210). Z kolejnej wizytacji wiadomo, że był to pozytyw przenośny [ruchomy, mobilny]: „Chorus Musicus simplex ligneus cum Organo parvo mobili” (AKMK, sygn. AV 25, 155). Jeszcze więcej szczegółów przekazuje wizytacja z 1748 r., w której określono wielkość rzeczonego pozytywu: „[...] organum decens vocum septem vulgo o siedmiu głosach" (AKMK, sygn. AV 46, 33).

Począwszy od końca XVIII w. pojawiają się już zapisy o złym stanie zachowania instrumentu. W protokole wizytacji z 1782 r. odnotowano: „Chór z złym pozytywem” (BWSDS, sygn. J 1476, 88). Przed rokiem 1818 instrument został naprawiony staraniem ówczesnego proboszcza, co odnotowano w opisie historycznym kościoła (APR, sygn. RGR I 5768, 9). W kolejnych latach pozytyw znów wymagał naprawy, co zapisywano w kolejnych źródłach: w inwentarzu z 1837 r.: „Organ mały zdezelowany” (ADS, Akta parafii Iwaniska 1800-1841, 54r), którego wartość oszacowano jedynie na 80 Złp, w 1868 r., oraz „Chor z organem potrzebującym reperacyi” (ADS, Akta parafii Iwaniska $1845-1983,145 \mathrm{v})$. Więcej szczegółów o pozytywie przekazuje inwentarz z roku 1887: „Organ umieszczony jest na chórze, posiada 2 miechy i $7 \mathrm{~m}$ głosów, składa się z piszczałek na froncie cynowych, a wewnątrz drewnianych, pomalowany na kolor biały" (ADS, Akta parafii Iwaniska 1845-1983, 158v). Instrument spłonął wraz z całym kościołem w $1898 \mathrm{r}$. 
Obecnie w kościele parafialnym w Iwaniskach funkcjonują 16-głosowe organy (II M+P) zbudowane przez firmę Adolfa Homana w 1906 r.

\section{Malice, parafia pw. Matki Bożej Wniebowziętej}

Parafia erygowana przed rokiem 1326. Kościół pierwotny powstał w 1326, natomiast kolejny, wykonany z drewna modrzewiowego i datowany na XVI wiek, spłonął w 1944 r. Obecna świątynia, zbudowana $\mathrm{z}$ kamienia ciosowego w latach 1968-1974, jest trójnawowa w stylu neoromańskim (Rocznik Diecezji 264).

\subsection{Organy sprzed $1727 \mathrm{r}$.}

W protokole wizytacji biskupiej z 1727 r. odnotowano istnienie 8-głosowych organów: „Chorus Musicalis cum Organo vocum octo depictus” (AKMK, sygn. AV 22, 177). Więcej informacji o rodzaju i wyglądzie instrumentu przekazuje kolejna wizytacja z 1736 r.: „Chorus Musicus ligneus depictus cum Organo stabili in parte deaurato et depicto nigro colore" (AKMK, sygn. AV 25, 96). Organy te wzmiankowane są w kolejnych źródłach, do roku 1868 (AKMK, sygn. AV 46, 387; sygn. AV 51, 257r-257v; BWSDS, sygn. J 1476, 234; ADS, Akta parafii Malice 1848-1983, 78v, 118v; APR, sygn. RGR I 6032, 227). Począwszy od 1782 r. pojawiają się wzmianki o ich złym stanie zachowania (,zepsute, potrzebujące reperacyi”). Prace remontowe podjęto w roku 1862: „Na robotę organmistrza. Organ cały wyreperować przez dorobienie nowej lady wietrznej, klap klawiatury, przetopienie pogiętych piszczałek itd. oraz zrobienie nowych zupełnie miechów w miejsce zniszczonych" (APR, sygn. RGR I 6033, 798). W protokole rewizyjno-odbiorczym z 1862 r. stwierdzono wykonanie naprawy: „Organ kompletnie i dokładnie wyreperowano i Miechy nowe zrobione przyjmuje się według anszlagu 90 Rs" (APR, sygn. RGR I 6033, 799).

\subsection{Organy z ok. 1879 r.}

Kolejny instrument powstał ok. 1879 r. W inwentarzu kościoła z roku 1885 odnotowano: „Chór za staraniem Śp. Księdza Homanna, na miejscu starego, nowo w roku 1879 zbudowany, na którym znajduje się organ nowy, fundowany z dobrowolnych składek parafian miejscowych, również za staraniem wyż wspomnianego śp. Księdza Homanna” (ADS, Akta parafii Malice 1848-1983, 153v). Wiadomo, że organy zbudował Antoni Adolf Homan, organmistrz zamieszkały w pobliskim Opatowie, brat proboszcza malickiego, ks. Pawła Homana. Instrument wymieniany jest w kolejnych inwentarzach - z lat 1906 i 1933 (ADS, Akta parafii Malice 1848-1983, 173v). Wiadomo, że miał 6 głosów. Został zniszczony wraz całym kościołem w czasie działań wojennych w 1944 r., więc do liturgii akompaniowano na fisharmonii. Obecnie funkcjonują organy elektronowe. 


\section{Modliborzyce, parafia pw. św. Benedykta}

Parafia erygowana przed rokiem 1326, a pierwotny kościół istniał już w 1326 r. Obecna świątynia zbudowana ok. 1470 r., powiększona w 1896, spalona w czasie działań wojennych w roku 1944. Została odbudowana w latach 1949-1962 (Rocznik Diecezji 266).

\subsection{Organy sprzed $1727 \mathrm{r}$.}

Pierwsza informacja o organach w parafii Modliborzyce, na jaką udało się natrafić autorce niniejszego opracowania, pochodzi z wizytacji z 1727 r. Odnotowano w niej: „Chorus Musicalis cum Organo fixo vocum octo” (AKMK, sygn. AV 22, 197-198). Instrument wymieniany jest w kolejnych źródłach do roku 1864 (AKMK, sygn. AV 25, 132; sygn. AV 46, 53; sygn. AV 51, 55v; BWSDS, sygn. J 1476, 80; APR, sygn. RGR I 6077, 41, 201; ADS, Akta parafii Modliborzyce 1852-1983, k. 56v). Wiadomo, że miał osiem głosów, tympan, piszczałki cynowe i drewniane, dwa miechy, pomalowany był na kolor czarny.

\subsection{Organy z $1884 \mathrm{r}$.}

W inwentarzu kościoła z 1887 r. znajduje się informacja o kolejnym instrumencie: „Organ nowy o sześciu głosach zbudowany 1884 r. przez Jana Szrejberta sposobem administracyinym tj. parafia złożyła rs. 350 proboszcz dał materyał i przez rok życie majstrom" (ADS, Akta parafii Modliborzyce 1852-1983, k. 93v) ${ }^{1}$.

\subsection{Organy z $1902 \mathrm{r}$.}

Trudny do zinterpretowania jest zapis w inwentarzu modliborzyckiego kościoła z 1932 r. świadczący o tym, że już po osiemnastu latach funkcjonowania organów Szrejberta „sprawiono” następny instrument: „Na chórze umieszczony organ ośmiogłosowy z miechami. W organach część piszczałek drewnianych, część cynowych. Organy sprawione w roku 1902, struktura organowa ozdobiona rzeźbami, pomalowana na kolor jak ołtarze" (ADS, Akta parafii Modliborzyce 1852-1983, k. 139). Instrument spłonął wraz z kościołem w czasie działań wojennych w 1944 r.

Obecnie w Modliborzycach funkcjonują 8-głosowe organy $(\mathrm{M}+\mathrm{P})$ zbudowane w latach 1964-1967 przez Józefa Wójcika z Garbatki (Szymanowicz, Zarys biografii 93-94).

\footnotetext{
${ }^{1}$ Jan Szrejbert miał warsztat organmistrzowski we Włocławku, przy ul. Żelaznej.
} 


\section{Opatów, parafia św. Marcina, kolegiata}

Parafia erygowana w XII w., kościół pierwotny pochodzi z XII w., spalony przez Tatarów w wieku XVI, następnie odbudowany. Wielokrotnie restaurowany w ciągu wieków (Rocznik Diecezji 267-68).

Organy w kolegiacie opatowskiej były przedmiotem pracy mgr. Tomasza Stańka, napisanej w Katedrze Instrumentologii KUL pod kierunkiem ks. prof. Jana Chwałka (Staniek, Organy w Kolegiacie). Autorka niniejszego artykułu wykorzystała wyniki badań T. Stańka, jednocześnie przeprowadziła własną kwerendę źródeł w Archiwum Diecezjalnym w Sandomierzu i Archiwum Państwowym w Radomiu.

\subsection{Organy z XVI w.}

Pierwsze informacje o organach w kolegiacie opatowskiej pochodzą z XVI i XVII w. Dotyczą głównie złego stanu instrumentu i konieczności naprawy. Szczegóły na podstawie Archiwum Kapituły Kolegiackiej w Opatowie, zob. w pracy T. Stańka (Staniek, Organy w Kolegiacie 40-42).

\subsection{Organy z $1746 \mathrm{r}$.}

Historia instrumentu sięga 1745 r., kiedy to zawarta została umowa z organmistrzem Kiehlem z Opawy na wykonanie nowych organów, które mistrz zobowiązał się ukończyć w roku 1746 przed świętem św. Marcina (Staniek, Organy w Kolegiacie 42). Wiadomo, że instrument był remontowany w roku 1850. W protokole rewizyjno-odbiorczym odnotowano: „Za zreperowanie całego organu z pozytywem o 24 głosach w Manuale, Pedale i 4 miechach. Koszt 916 Rub" (APR, sygn. RGR I 6202, 354). Potrzebę kolejnej naprawy orzeczono w 1887 r.: „Organ pięknej struktury, na dwie części przedzielony, wielkości odpowiedniej do budowy Kościoła głosów 24 rejestrów trzy potrzebuje naprawy i restauracji” (ADS, Akta parafii św. Marcina Opatów 1866-1983, 244v).

Instrument Kiehla funkcjonował do 1889 r., kiedy to gruntownej przebudowy dokonał Adolf Homan. Zachował dawny, kulisowy prospekt w stylu regencyjnym. Zlikwidował sekcję pozytywu wbudowaną w balustradę chóru, zredukował liczbę głosów do osiemnastu, wymienił trakturę i wiatrownice, zachował natomiast część piszczałek. Opis organów po dokonanej przebudowie zachował się w Inwentarzu kościoła z 1932 r. (ADS, Akta parafii św. Marcina Opatów 1866-1983, 417). Instrument funkcjonuje do dziś. 


\section{Opatów, parafia pw. Wniebowzięcia NMP, OO. Bernardyni}

Kościół pierwotny z XII w., obecny z XV w., który w wieku XVII i XVIII został przebudowany (Rocznik Diecezji 270-71).

Organy w kościele klasztornym OO. Bernardynów w Opatowie były przedmiotem rozprawy o. dr. Mieczysława Juliana Śmierciaka, napisanej w Katedrze Instrumentologii KUL pod kierunkiem ks. prof. Jana Chwałka (Śmierciak). Autorka niniejszego artykułu wykorzystała wyniki badań o. Śmierciaka, a jednocześnie przeprowadziła własną kwerendę źródeł w Archiwum Diecezjalnym w Sandomierzu i Archiwum Państwowym w Radomiu.

\subsection{Organy z I poł. XVII w.}

Z 1674 r. pochodzi pierwsza źródłowa informacja o organach w kościele klasztornym: ,[...] restaurowane są organy z gruntu, bo prawie połowa piszczałek nie grała, i przeniesiono je dla lepszej resonancyi na Wielki chór. Przydatne do tego są dwa głosy, to jest Mixtura i Flet dolny. Bębny też sporządzono do nich" (Śmierciak 115-16).

\subsection{Organy z $1730 \mathrm{r}$.}

W roku 1728 wybudowano w kościele klasztornym nowy chór, na którym organmistrz A. F. Jugiewicz ustawił nowe organy. Głównymi fundatorami byli: książę Konrad Sanguszko, ksiądz Szewierski, kanonik kielecki i opatowski, oraz Józef Zarzycki, wójt opatowski (Śmierciak 116). W aktach kościoła znajduje się zapis: „1750 roku i następnych lat wspaniałe były organy na basowych piszczałkach wyryty nawet rok 1711. Kilka razy restaurowane z miechem pedałowym, ledwie jeszcze grają, potrzeba odnowienia" (ADS, Akta parafii Wniebowzięcia NMP Opatów 1865-1983, npg). Wykorzystano, być może, część piszczałek z poprzedniego instrumentu. Do tak złego stanu instrumentu doprowadziła kasata klasztoru. Bernardyni powrócili do Opatowa w 1939 r. Mimo trudności spowodowanych II wojną światową, przeprowadzali remonty klasztoru i kościoła, między innymi organów (Śmierciak 116).

W kościele bernardyńskim, w latach 1963-1967, nowy, 10-głosowy instrument $(\mathrm{M}+\mathrm{P})$ zbudował Józef Wójcik z Garbatki, zachowując XVIII-wieczną szafę organową (Szymanowicz, Zarys biografii 95-96).

\section{Ptkanów, parafia pw. św. Idziego}

Parafia została erygowana przed rokiem 1325 . Kościół obecny pochodzi z końca XIV lub początku XV w., rozbudowany w 1909. Jest jednonawowy, w stylu gotyckim (Rocznik Diecezji 273). 


\subsection{Pozytyw sprzed 1718 r.}

Pierwsza informacja o instrumencie w kościele ptkanowskim pochodzi $\mathrm{z}$ wizytacji przeprowadzonej $\mathrm{w}$ latach 1718-1719. Wymieniony jest $\mathrm{w}$ niej dobry pozytyw umieszczony na chórze muzycznym: „Chorus Musicus supra portam ligneus cum instrumento positivo fixo bono" (AKapMK, sygn. AVCap. $58,151)$. Informacje o rzeczonym pozytywie znajdują się w kolejnych XVIIIwiecznych źródłach (AKMK, sygn. AV 45, 5r; BWSDS, sygn. J 1476, 253). Wiadomo, że instrument miał siedem głosów.

W inwentarzu kościoła z 1821 r. wymieniony jest „Chór na kolumnach, przyozdobiony snycerską rzeźbą i Organy pomierne zewnątrz snycerską robotą ozdobione. Miechy 2" (ADS, Akta parafii Ptkanów 1801-1827, 110v). W inwentarzu z 1862 r. odnotowano: „Organ dość zdezelowany znacznej potrzebuje reperacyi w miechach i piszczałkach" (ADS, Akta parafii Ptkanów 1801-1827, 53r).

W kolejnym inwentarzu wymieniony już jest nowy instrument: „Chór restaurowany w roku 1883 pomalowany na kolor marmurowy, spoczywa na $4^{\text {ch }}$ filarach, z Organem nowym budowanym w roku 1883 z fabryki p. Adolfa Homana za Rs. 675, o $6^{\text {ciu }}$ głosach z miechem cylindrowym" (ADS, Akta parafii Ptkanów 1801-1827, npg). Instrument istnieje.

\section{Ruszków, parafia pw. św. Stanisława BM}

Parafia erygowana w I poł. XV w. Pierwszy kościół modrzewiowy został zbudowany w 1409 r. Obecny, murowany, pochodzi z roku 1798 (Rocznik Diecezji 275).

\subsection{Pozytyw sprzed $1718 \mathrm{r}$.}

W protokole wizytacji przeprowadzonej w 1718-1719 r. wymieniony jest wyreperowany 9-głosowy pozytyw stały: „Chorus Musicus supra portam Porticus ligneus cum instrumento positivo fixo novem vocum reparato" (AKapMK, sygn. AVCap. 58, 148). Rzeczony instrument wzmiankowany jest w kolejnych źródłach (AKMK, sygn. AV 45, 11r; BWSDS, sygn. J 1476, 332). W 1782 r. orzeczono, że jest zepsuty, a chór starty z malowania.

Po wybudowaniu nowej świątyni instrument został przeniesiony na nowy chór muzyczny (ADS, Akta parafii Ruszków 1800-1844, 26r). Więcej informacji przekazuje kolejny inwentarz, z roku 1822. Chór był drewniany, marmurowo malowany, na nim umieszczony „Organ o $9^{\text {u }}$ głosach przyozdobiony roznemi sztukateryami pozłacanemi” (ADS, Akta parafii Ruszków 1800-1844, 57r). Instrument wymieniany jest w kolejnych źródłach. Zapis w inwentarzu z 1845 r. przekazuje inną liczbę głosów: „Organ o osmiu głosach z wszelkiemi 
rekwizytami” (ADS, Akta parafii Ruszków 1845-1983, 35r; APR, sygn. RGR I 6370, 137). W Protokole wizytacji kanonicznej z 1889 r. oceniono, że „Organ [jest] dość przyzwoity” (ADS, Akta parafii Ruszków 1845-1983, 87v).

Rok później, w 1890, staraniem ks. Macieja Grudnia powstały nowe 8-głosowe organy. Zbudował je Władysław Kołodziejski z Piotrkowa Trybunalskiego. Instrument istnieje (Staniek, Organy Władysława 142-55).

\section{Strzyżowice, parafia pw. św. Bartłomieja Ap.}

Parafia erygowana przed $1326 \mathrm{r}$. Pierwsza, drewniana świątynia pochodziła z roku 1326. Obecny, murowany kościół zbudowano w 1783 r. Został zniszczony w czasie działań wojennych w roku 1944, a w latach 1946-1954 odbudowany (Rocznik Diecezji 276-77).

\subsection{Pozytyw sprzed $1727 \mathrm{r}$.}

Małe organy istniały w kościele w Strzyżowicach już w 1727 r., o czym świadczy zapis w protokole wizytacyjnym: „Chorus Musicalis cum Organo parvo" (AKMK, sygn. AV 22, 202). Instrument wymieniany jest w kolejnych XVIII-wiecznych źródłach (AKMK, sygn. AV 25, 140; sygn. AV 46, 99; sygn. AV 57, 63r; BWSDS, sygn. J 1476, 73). Na ich podstawie wiadomo, że pozytyw miał 6 głosów, pomalowany był różnymi kolorami. W kolejnych latach pogarszał się stan jego zachowania. W aktach Lustracji parafii z 1819 r. odnotowano: „Chór drewniany na którym Pozytywek zdezylowany” (ADS, Akta parafii Strzyżowice [1819] 1845-1983, 12v).

\subsection{Organy z ok. 1834 r.}

Inwentarz z 1834 r. przekazuje następującą informację: „Chór z tarcic niebiesko malowany $[\ldots]$ na ktorym organ nowy o osmiu głosach niebiesko malowany z Tonbasem i trzema małemi dzwonkami z dwoma pod organem miechami, nakładem teraznieyszego X. Plebana fundowany, do ktorego częściowo przyłożył się WX Dziekanowicz Kanonik Katedry Sandomierskiey, w ilości Złpol 414 otaxowany" (ADS, Akta parafii Strzyżowice 1803-1843, 85r). Ówczesnym proboszczem był ks. Jerzy Szczepański. Podobne w treści zapisy zawierają kolejne inwentarze, z roku 1840 (ADS, Akta parafii Strzyżowice 1803-1843, 143v) i 1849 (ADS, Akta parafii Strzyżowice [1819] 1845-1983, npg). Użyty w źródłach termin Tonbas z pewnością oznacza tympan, urządzenie dodatkowe złożone z dwóch współbrzmiących piszczałek, których dźwięk imitował bicie w bęben lub kocioł. Na określenie tympanu w historii organów używano wielu nazw (Słownik terminologiczny 166). Instrument był restaurowany w roku 1866 staraniem proboszcza ks. Stanisława Giełżyńskiego (Gołos 359; Wiśniewski 431). 
9.3. Organy z $1909 \mathrm{r}$.

Już w roku 1909 powstał kolejny instrument za sumę 1000 rubli. Miał osiem głosów, był ozdobiony rzeźbami i dwoma wazonami, pomalowany na kolor ciemny i pozłacany. Informację taką przekazuje inwentarz kościoła spisany w roku 1932 (ADS, Akta parafii Strzyżowice [1819] 1845-1983, npg). Organy zostały zniszczone wraz z kościołem w czasie działań wojennych w 1944 r., do liturgii akompaniowano na fisharmonii.

Obecnie funkcjonują 11 -głosowe organy zbudowane w 1980 r. przez Józefa Bułę z Krakowa.

\section{Włostów, parafia pw. św. Jana Chrzciciela}

Parafia erygowana przed rokiem 1326. Pierwszy kościół zbudowano w I poł. XIV w., w XVIII w. był przebudowany. Został spalony w czasie działań wojennych w roku 1944, następnie odbudowany (Rocznik Diecezji 278).

\subsection{Organy sprzed $1727 \mathrm{r}$.}

Pierwsza informacja o instrumentarium we włostowskim kościele, na jaką autorce udało się natrafić, pochodzi z roku 1727 . W protokole wizytacyjnym zapisano wówczas: „Chorus ligneus picturis adornatus in eo est Organum fixum vocum Decem" (AKMK, sygn. AV 22, 236). W kolejnych źródłach potwierdzone jest istnienie 10-głosowych organów stałych, częściowo złoconych, a częściowo malowanych (AKMK, sygn. AV 25, 203; sygn. AV 46, 112; sygn. AV 51, 73r; BWSDS, sygn. J 1476, 61). W 1782 r. instrument był ,zgruntu od Rządcy reparowany". XIX-wieczne zapisy świadczą o złym stanie zachowania włostowskich organów (ADS, Akta parafii Włostów 1838-1983, 105r).

\subsection{Organy z $1883 \mathrm{r}$.}

W inwentarzu kościoła z 1886 r. wymieniony został „Organ nowy”, oszacowany na 1350 rs. (ADS, Akta parafii Włostów 1838-1983, 117v). Z kolejnych źródeł wiadomo, że był to instrument 8-głosowy, zbudowany przez Adolfa Homana w 1883 r. Został zniszczony w czasie działań wojennych w 1944 r.

\subsection{Organy Władysława Kołodziejskiego z 1892 r.}

Do odbudowanego po zniszczeniach wojennych kościoła włostowskiego sprowadzone zostały 6-głosowe używane organy, zbudowane przez Władysława Kołodziejskiego z Piotrkowa Trybunalskiego. W 1987 r. instrument powtórnie translokowano, tym razem do kościoła parafialnego w Nadolnej 
(ob. diecezja radomska), gdzie istnieje do dziś (Szymanowicz, Organy w kościołach diecezji 311-12).

Obecnie funkcjonują 12-głosowe organy zbudowane w latach 1986-1987 przez Włodzimierza Truszczyńskiego z Warszawy.

\section{Wszechświęte alias Grocholice, parafia pw. Wszystkich Świętych}

Parafia erygowana przed 1325 r. Kościół zbudowano z kamienia ciosanego w 1460 r. i rozbudowano w XVIII w. W roku 1886 został spalony, a następnie odbudowany (Rocznik Diecezji 280).

\subsection{Pozytyw z XVII w.}

W protokole wizytacyjnym z 1718/19 odnotowano: „Chorus Musicus supra portam ad porticum ligneus cum instrumento positivo reparato 1717 fixo et stabili” (AKapMK, sygn. AVCap. 58, 145). Informacja o naprawie instrumentu świadczy, że pochodził najprawdopodobniej z XVII w. Z kolejnego źródła wiadomo, że pozytyw miał siedem głosów (AKMK, sygn. AV 45, 8r). W 1782 r. określono go jako stary.

\subsection{Pozytyw z $1800 \mathrm{r}$.}

Nowy instrument został wybudowany w roku 1800 (Wiśniewski 197). Pewne szczegóły przekazuje opis kościoła z 1823 r.: „Na Chorze iest Pozytyw o dziewięciu głosach malowany i pozłacany podobnie ołtarzom z dwiema miechami. Ten wraz z Chorem kosztem Jw. Jana z Dukli Hrabi Małachowskiego sprawiony. Oszacowany 200 zł" (APR, sygn. RGR I 5738, 106). W 1848 r. orzeczono, że „miechy i głosy wymagają reparacyi” (ADS, Akta parafii Wszechświęte 1845-1983, 45r).

Kolejne organy zostały zbudowane ok. 1880 r. przez Władysława Kołodziejskiego z Piotrkowa Trybunalskiego, kosztem 1200 rubli. Instrument funkcjonuje do dziśs, ma 9 głosów $(\mathrm{M}+\mathrm{P})$.

\section{PODSUMOWANIE DANYCH O ORGANACH NIEZACHOWANYCH}

\section{Liczba organów}

W parafiach obecnie przynależących do dekanatu opatowskiego stwierdzono istnienie 22 organów niezachowanych. Jedne z nich pochodziły z XVI w., troje z wieku XVII, jedenaścioro z XVIII w., pięcioro z XIX i dwoje z wieku XX. Proweniencję XVII-wieczną dla dwóch instrumentów - w Gierczycach 
i Wszechświętych - ustalono w sposób pośredni. Jeżeli bowiem w źródłach z początku XVIII w. stwierdzony jest zły stan zachowania organów, to można przypuszczać, że pochodziły one $\mathrm{z}$ wieku wcześniejszego. Najwięcej instrumentów niezachowanych, po trzy, udało się ustalić w parafiach Strzyżowice i Włostów.

Pięć instrumentów unicestwiły pożary. W 1898 r. spalił się drewniany kościół w Iwaniskach wraz z całym wyposażeniem. Duże straty przyniosły także działania wojenne w 1944 r. Wówczas zniszczone zostały organy w Malicach, Modliborzycach, Strzyżowicach i Włostowie. Po odbudowaniu świątyni włostowskiej sprowadzono doń używany instrument zbudowany przez Władysława Kołodziejskiego w 1892 r. W roku 1987 translokowano go powtórnie, aby zrobić miejsce nowym organom. Przeniesiony do Nadolnej, istnieje do dziś.

Zachowane zostały trzy XVIII-wieczne szafy i prospekty organowe, w których umieszczono nowe instrumenty - w Gierczycach, w kolegiacie w Opatowie i kościele klasztornym w Opatowie. Na szczególną uwagę zasługuje bogato zdobiony dekoracją snycerską, regencyjny prospekt o wklęsło-wypukłym przełamującym się konturze w kolegiacie św. Marcina w Opatowie.

\section{Nazewnictwo}

Na określenie organów używa się dwóch podstawowych terminów: w języku łacińskim - organum i positivum, w języku polskim - organy i pozytyw. W praktyce terminy te występują $\mathrm{w}$ różnych wersjach i w połączeniu $\mathrm{z}$ dookreśleniami przymiotnikowymi. Poniżej zamieszczono wszystkie wersje nazewnictwa występujące w przebadanych źródłach:

- XVIII wiek: organum, organum fixum, organum mobile, organum parvum stabile, organum stabile, organum positivum, organy, posijtew szkatulnij, positivum, positivum fixum, positivum fixum et stabile, pozytyw;

- XIX wiek: organ, organy, pozytew stoiacy, pozytyw, pozytywek;

- XX wiek: organ, organy.

$\mathrm{Z}$ powyższego wynika, że w źródłach użytych zostało 15 wersji nazw organów. Źródła z wieku XVIII w większości napisane są w języku łacińskim, stąd nazewnictwo łacińskie.

Termin organum przybiera trzy formy - organ, organum, organy. Termin positivum przybiera cztery formy: posijtew, positivum, pozytyw, pozytywek. Raz występuje forma alternatywnie złożona, tj. organum positivum. Przy niektórych nazwach użyto dookreśleń przymiotnikowych wskazujących na rodzaj instrumentu. Nazwy organum fixum [stabile] i pozytew stoiacy wskazują, że instrument był zamocowany na stałe. Organum mobile, pozytyw szkatulny 
- były to instrumenty przenośne, czyli konstrukcyjnie przystosowane do przenoszenia. Zdrobnienie pozytywek, wskazuje na mały rozmiar instrumentu.

\section{Lokalizacja i wygląd zewnętrzny}

We wnętrzu świątyni organy najczęściej umieszczane są na chórze muzycznym, a chór lokalizowany jest nad wielkimi drzwiami kościoła, naprzeciw głównego ołtarza. Na określenie chóru muzycznego używa się łacińskiego terminu chorus i polskiego chór. W przebadanych źródłach użytych zostało dziewięć form tych nazw: chorus, chorus musicalis, chorus musicus, chorus pro cantoribus, chor, chór, chór muzyczny, chur, wielki chór.

Wszystkie organy z dekanatu opatowskiego zlokalizowane były na chórze muzycznym. Wyjątkiem był XVII-wieczny instrument w kościele bernardyńskim w Opatowie, który pierwotnie umieszczony był w chórze zakonnym, a później przeniesiony na wielki chór [chór muzyczny]. W źródłach określano konstrukcję i wygląd chórów. Chóry były drewniane, z tarcic, proste, na kolumnach, na filarach, z balustradą. Jeżeli chodzi o wygląd - malowane (kolor marmurowy, niebieski), przyozdobione rzeźbą snycerską.

Kilkakrotnie określono także wygląd organów - były malowane (kolor biały, czarny, ciemny, różne kolory), zdobione snycerką, rzeźbami, częściowo złocone. Podkreślano także podobieństwo organów do ołtarzy. Takie ujednolicenie stylistyczne i kolorystyczne było powszechną praktyką.

\section{Wielkość i rodzaj organów}

Podstawą do określenia wielkości organów jest liczba głosów. W dekanacie opatowskim znana jest wielkość 17 spośród 20 instrumentów:

- 6 głosów: Gierczyce (XVII w.), Strzyżowice (XVIII), Malice (XIX), Modliborzyce (XIX), Włostów (XIX);

-7 głosów: Wszechświęte (XVII w.), Gierczyce (XVIII);

-8 głosów: Malice (XVIII w.), Modliborzyce (XVIII), Modliborzyce (XX), Strzyżowice (XIX), Włostów (XIX), Strzyżowice (XX);

- 9 głosów: Gierczyce (XVIII w.), Wszechświęte (XVIII);

- 8 lub 9 głosów: Ruszków (XVIII w.);

- 10 głosów: Włostów (XVIII w.);

-24 głosy: Opatów, kolegiata (XVIII w.).

Nieznana pozostaje wielkość XVI-wiecznych organów kolegiaty w Opatowie oraz dwóch instrumentów z XVII i XVIII w. w opatowskim kościele klasztornym. W przypadku Ruszkowa liczba głosów została nieprecyzyjnie określona. Raz 
organy określono jako 8-głosowe, innym razem, jako 9-głosowe Taki zapis wynika prawdopodobnie $\mathrm{z}$ istnienia urządzeń dodatkowych, takich jak np. tympan, dzwonki, evacuant, które osoby spisujące inwentarz kościoła niekiedy zaliczały do głosów (włączane były podobnymi registrami).

Jeżeli chodzi o rodzaj instrumentów, sądząc po liczbie głosów, w zdecydowanej większości były to małe organy bez pedału, w nomenklaturze organologicznej określane jako pozytywy (Chwałek 25). W Gierczycach i Iwaniskach - przenośne [szkatulne], pozostałe - prawdopodobnie stałe, nieprzenośne. Tylko w dwóch instrumentach opatowskich zaznaczona została obecność sekcji pedału. W kolegiacie organy miały 24 głosy, dwa manuały i pedał, pozytyw wbudowany był $\mathrm{w}$ balustradę chóru. W kościele klasztornym mowa jest o inskrypcjach na piszczałkach basowych, można więc wnioskować o sekcji pedałowej.

\section{Inne szczegóły}

Ważne dla historii budownictwa organowego są nazwiska organmistrzów, którzy działali na badanym terenie. Znani są budowniczowie sześciu instrumentów. W 1730 r. organy dla kościoła Bernardynów w Opatowie zbudował Antoni Franciszek Jugiewicz, a w 1746 r. w kolegiacie opatowskiej - Wenzel Kiehl [Thiel]. Kolejne informacje dotyczą już wieku XIX. Na Ziemi Sandomierskiej działał Antoni Adolf Homan, który przez pewien czas mieszkał w Opatowie i tam miał swój warsztat. Na jego aktywność zawodową na tym terenie niewątpliwie miał wpływ fakt, że był bratem ks. Pawła Homana, proboszcza parafii Malice. Dziełem tego pierwszego były nieistniejące już organy w Malicach i we Włostowie oraz funkcjonujące do dziś w Iwaniskach, kolegiacie opatowskiej i Ptkanowie. W Modliborzycach instrument zbudował majster z Włocławka, Jan Szrejbert. Kolejnym, znanym z nazwiska budowniczym, był Władysław Kołodziejski z Piotrkowa Trybunalskiego. Organy pochodzące z jego warsztatu po II wojnie światowej funkcjonowały we Włostowie, skąd w 1987 r. zostały translokowane do Nadolnej, gdzie służą do chwili obecnej.

Znane są także nazwiska fundatorów trzech instrumentów. W kościele bernardyńskim w Opatowie organy w 1730 r. ufundowali: książę Konrad Sanguszko, ksiądz Szewierski - kanonik kielecki i opatowski oraz wójt Opatowa, Józef Zarzycki. W Strzyżowicach fundatorami instrumentu ok. 1834 r. byli tamtejszy proboszcz ks. Jerzy Szczepański oraz ks. Józef Dziekanowicz, kanonik katedry sandomierskiej. Pozytyw w parafii Wszechświęte ufundował hrabia Jan Małachowski w 1800 r. 
Źródłowe zapisy o szczegółach konstrukcyjnych dotyczą miechów, piszczałek i urządzeń dodatkowych. W badanym okresie stosowane były miechy klinowe. Aby mogły pełnić swoją funkcję, musiało być ich przynajmniej dwa. Wiadomo, że dwa miechy znajdowały się w instrumentach w Iwaniskach, Modliborzycach, Strzyżowicach i Wszechświętych. Duże organy w kolegiacie opatowskiej zasilały cztery miechy. Określenie miech pedałowy, w odniesieniu do instrumentu klasztornego, z pewnością dotyczy nożnej dźwigni do kalikowania. Trzy informacje odnoszą się materiału, z jakiego wykonano piszczałki. Były to piszczałki cynowe i drewniane. W instrumentach funkcjonowały także urządzenia dodatkowe: tympan w Modliborzycach, a w Strzyżowicach tympan i trzy małe dzwonki - można przypuszczać, że przymocowane do wirującej gwiazdki [Cymbelstern]. Interesujący jest zapis odnośny do organów klasztornych. Do XVII-wiecznego instrumentu, przy okazji translokacji z chóru zakonnego na chór muzyczny, dodano Miksturę, Flet dolny i Bębny.

Prezentowany artykuł jest kolejnym z cyklu tekstów o organach Ziemi Sandomierskiej i przyczynkiem do monografii budownictwa organowego i kultury muzycznej diecezji sandomierskiej. Kolejny, przygotowywany przez autorkę, będzie dotyczył instrumentarium dekanatów - klimontowskiego i koprzywnickiego.

\section{BIBLIOGRAFIA}

ŹRÓDŁA

Archiwum Diecezjalne w Sandomierzu (akta bez sygn.) [ADS]:

Akta parafii Gierczyce 1800-1840

Akta parafii Gierczyce [1826] 1845-1983

Akta parafii Iwaniska 1800-1841

Akta parafii Iwaniska 1845-1983

Akta parafii Malice 1811-1843

Akta parafii Malice 1848-1983

Akta parafii Modliborzyce 1852-1983

Akta parafii św. Marcina Opatów 1816-1826

Akta parafii św. Marcina Opatów 1827-1834

Akta parafii św. Marcina Opatów 1835-1844

Akta parafii św. Marcina Opatów 1844-1858

Akta parafii św. Marcina Opatów 1855-1865

Akta parafii św. Marcina Opatów 1866-1983 
Akta parafii Wniebowzięcia NMP Opatów 1865-1983

Akta parafii Ptkanów 1801-1827

Akta parafii Ptkanów 1848-1983

Akta parafii Ptkanów od 1984

Akta parafii Ruszków 1800-1844

Akta parafii Ruszków 1845-1983

Akta parafii Strzyżowice 1803-1843

Akta parafii Strzyżowice [1819] 1845-1983

Akta parafii Włostów 1812-1839

Akta parafii Włostów 1838-1983

Akta parafii Wszechświęte 1806-1844

Akta parafii Wszechświęte 1845-1983

Archiwum Kapituły Metropolitalnej w Krakowie [AKapMK]:

Wizytacja dekanatów Urzędów, Zawichost, Opatów z 1718/19 r., sygn. AVCap. 58 [sygn. OABMK 3266]

Archiwum Kurii Metropolitalnej w Krakowie [AKMK]:

Wizytacja dekanatów: Rudnik, Miechocin, Koprzywnica, Połaniec z 1727 r., sygn. AV 22 [sygn. OABMK 3294]

Wizytacja dekanatów: Koprzywnica, Połaniec, Rudnik, Miechocin z 1736 r., sygn. AV 25 [sygn. OABMK 3297]

Wizytacja dekanatów: Urzędów, Opatów, Zawichost z 1748 r., sygn. AV 45 [sygn. OABMK 3317]

Wizytacja dekanatów: Połaniec, Koprzywnica z 1748 r., sygn. AV46 [sygn. OABMK 3318]

Wizytacja dekanatów: Połaniec, Miechocin, Rudnik, Koprzywnica z 1765/66 r., sygn. AV 51 [sygn. OABMK 3323]

Archiwum Państwowe w Radomiu [APR]:

Akta funduszów kościoła w Gierczycach 1820-1866 [1816], sygn. RGR I 5690

Akta funduszów kościoła w Grocholicach v Wszechświętych 1820-1857, sygn. RGR I 5738

Akta funduszów kościoła w Malicach Kościelnych 1820-1866, sygn. RGR I 6032

Akta funduszów wszelkich kościoła w Modliborzycach 1820-1866, sygn. RGR I 6077

Akta funduszów XX Bernardynów w Opatowie 1850-1866, sygn. RGR I 6200

Akta funduszów kościoła w Ruszkowie 1820-1863, sygn. RGR I 6370

Akta reperacji kościoła w Iwaniskach 1816-1863, sygn. RGR I 5768

Akta reperacji kościoła w Malicach 1829-1857, sygn. RGR I 6033

Akta reperacji kościoła w Opatowie 1847-1863, sygn. RGR I 6202

Akta reperacji kościoła w Ptkanowie 1821-1865, sygn. RGR I 6279

Biblioteka Wyższego Seminarium Duchownego w Sandomierzu [BWSDS]:

Wizytacja dekanatów: Połaniec, Koprzywnica, Opatów, Zawichost z 1782 r., sygn. J 1476

\section{OPRACOWANIA}

Chwałek, Jan. Budowa organów. Ministerstwo Kultury i Sztuki, 1971.

Gołos, Jerzy. Polskie organy i muzyka organowa. Instytut Wydawniczy PAX, 1972.

Kozera, Marek. „Kościoły dekanatu opatowskiego i ich wyposażenie w świetle wizytacji biskupa Załuskiego z 1748 r.”. Studia Sandomierskie, t. 22, 2015, ss. 15-32.

Lipa, Patryk. „Niezabytkowe organy na terenie województwa świętokrzyskiego”. Organy i ludzie II. Katalogi, opracowania, refleksje, red. Małgorzata Trzaskalik-Wyrwa, Uniwersytet Muzyczny Fryderyka Chopina, 2020, ss. 261-340. 
Rocznik Diecezji Sandomierskiej, red. Krzysztof Kida, Wydawnictwo Diecezjalne Sandomierz, 2010.

Stownik terminologiczny zabytków, z. 3, Instrumenty muzyczne, opr. Jerzy Gołos, Olga SiejnaBernady, Maria Zeyland-Korytek, Ośrodek Dokumentacji Zabytków - Wydawnictwa, 1995.

Smulikowska, Ewa. Prospekty organowe w dawnej Polsce. Zakład Narodowy Imienia Ossolińskich, Wydawnictwo Polskiej Akademii Nauk, 1989.

Staniek, Tomasz. Organy w Kolegiacie p.w. Św. Marcina w Opatowie. Studium historyczno-instrumentoznawcze. Archiwum Katolickiego Uniwersytetu Lubelskiego, 2000. Niepublikowana praca magisterska.

Staniek, Tomasz, „Organy Władysława Kołodziejskiego z roku 1890 w kościele parafialnym pw. Stanisława Biskupa w Ruszkowie”. Muzyka i śpiew kościelny. Kształcenie organistów, red. Jan Zimny, Wydawnictwo Diecezjalne Sandomierz, 2004, ss. 142-155.

Szymanowicz, Maria. „Organy w kościołach dekanatu ożarowskiego diecezji sandomierskiej (cz. I). Instrumenty niezachowane w świetle źródeł archiwalnych”. Roczniki Teologiczne, t. 64, z. 13, 2017, ss. 117-135.

Szymanowicz, Maria. „Organy w kościołach dekanatu zawichojskiego diecezji sandomierskiej. Instrumenty niezachowane w świetle źródeł archiwalnych”. Roczniki Humanistyczne, t. 67, z. 12, 2019, ss. 115-130.

Szymanowicz, Maria. Organy w kościołach diecezji radomskiej. Historia i stan obecny. Wydawnictwo Polihymnia, 2006.

Szymanowicz, Maria. „Zarys biografii i działalności organmistrzowskiej Józefa Wójcika z Garbatki (1904-1979)". Studia Sandomierskie, t. 8, 2001, ss. 85-104.

Śmierciak, Julian Mieczysław. Organy w kościołach bernardyńskich na terenie Polski. Studium historyczno-instrumentoznawcze. Archiwum Katolickiego Uniwersytetu Lubelskiego Jana Pawła II, 2008. Niepublikowana praca doktorska.

Wiśniewski, Jan. Dekanat opatowski. Druk. i Lit. „Jan Kanty Trzebiński”, 1907.

\section{ORGANY W KOŚCIOŁACH DEKANATU OPATOWSKIEGO DIECEZJI SANDOMIERSKIEJ. INSTRUMENTY NIEZACHOWANE W ŚWIETLE ŹRÓDEŁ ARCHIWALNYCH}

$$
\text { Streszczenie }
$$

Niniejszy artykuł powstał w oparciu o XVIII, XIX i XX-wieczne źródła przechowywane w archiwach w Krakowie, Sandomierzu i Radomiu. Analiza uzyskanych danych pozwoliła na wysnucie następujących wniosków. Na terenie dekanatu opatowskiego w jedenastu kościołach stwierdzono istnienie dwudziestu dwóch niezachowanych instrumentów. Były to niewielkie organy, od sześciu do dziesięciu głosów, w zdecydowanej większości z jedną klawiaturą ręczną. Wyjątkiem był 24-głosowy instrument w kolegiacie w Opatowie, z dwoma manuałami i pedałem. Niektóre organy wyposażone były w urządzenia dodatkowe - tympan i dzwonki. Wszystkie znajdowały się na chórze muzycznym. Pełniły nie tylko funkcję muzyczną, malowane i zdobione snycersko stanowiły ważny element wystroju świątyń. Znane są nazwiska budowniczych sześciu instrumentów: Jugiewicz, Kiehl, Homan (2), Szrejbert i Kołodziejski.

Slowa kluczowe: organy; dekanat opatowski; diecezja sandomierska. 
ORGANS IN THE CHURCHES OF THE OPATÓW DEANERY, THE SANDOMIERZ DIOCESE: NON-PRESERVED INSTRUMENTS IN LIGHT OF ARCHIVAL SOURCES

\section{S u m m a ry}

This article is based on the eighteenth, nineteenth and twentieth-century sources stored in the archives in Kraków, Sandomierz and Radom. The analysis of the data obtained led to the following conclusions: in the Deanery of Opatów twenty-two non-preserved instruments in eleven churches were found. They were small organs, with six to ten voices, the vast majority with a single manual. The exception was the 24-voice instrument in the Opatów collegiate church, with two manuals and a pedal. Some organs were equipped with additional devices - a tympanum and bells. They were all located in the music gallery. They served not only a musical function, but, painted and decorated with carvings, they were also an important element of the decoration of the temples. We know the names of the builders of six instruments: Jugiewicz, Kiehl, Homan (2), Szrejbert, and Kołodziejski.

Keywords: organ; Opatów deanery; Sandomierz diocese. 